\title{
Lutibacter litoralis gen. nov., sp. nov., a marine bacterium of the family Flavobacteriaceae isolated from tidal flat sediment
}

Correspondence

Byung C. Cho

bccho@snu.ac.kr

\author{
Dong $\mathrm{H}$. Choi and Byung C. Cho
}

School of Earth and Environmental Sciences and Research Institute of Oceanography, Seoul National University, 56-1 Shillim-dong, Kwanak-gu, Seoul 151-742, Republic of Korea

\begin{abstract}
A rod-shaped marine bacterium, designated strain $\mathrm{CL}_{-\mathrm{TF} 09^{\top}}$, isolated from a tidal flat in Ganghwa, Korea, was characterized based on its physiological and biochemical features, fatty acid profile and phylogenetic position. 16S rRNA gene sequence analysis revealed a clear affiliation with the family Flavobacteriaceae. Strain CL-TF09 ${ }^{\top}$ showed the closest phylogenetic relationship with the genera Tenacibaculum and Polaribacter; sequence similarities between CL-TF09 ${ }^{\top}$ and the type strains of Tenacibaculum and Polaribacter species ranged from $90 \cdot 7$ to $91 \cdot 8 \%$. Cells of strain CL-TF09 ${ }^{\top}$ were non-motile and grew on solid media as yellow colonies. The strain grew in the presence of $1-5 \%$ sea salts, within a temperature range of $5-30{ }^{\circ} \mathrm{C}$ and at $\mathrm{pH} 7-8$. The strain had iso- $\mathrm{C}_{15: 0} 3-\mathrm{OH}(17 \cdot 4 \%)$, iso- $\mathrm{C}_{15: 0}(16 \cdot 7 \%)$, anteiso- $\mathrm{C}_{15: 0}(15 \cdot 1 \%)$ and iso- $\mathrm{C}_{16: 0} 3-\mathrm{OH}$ $(13.4 \%)$ as predominant fatty acids. The DNA G +C content was $33.9 \mathrm{~mol} \%$. Based on the physiological, fatty acid composition and phylogenetic data presented, strain CL-TF09 ${ }^{\top}$ is considered to represent a novel genus and species of the family Flavobacteriaceae, for which the name Lutibacter litoralis gen. nov., sp. nov. is proposed. The type strain is CL-TF09 ${ }^{\top}(=\mathrm{KCCM}$ $42118^{\top}=$ JCM $13034^{\top}$ ).
\end{abstract}

The family Flavobacteriaceae is one of the major branches of the phenotypically diverse phylum Bacteroidetes (Garrity \& Holt, 2001). Since the proposal of the family Flavobacteriaceae by Jooste (1985) and subsequent validation and emended description (Reichenbach, 1992; Bernardet et al., 1996, 2002), more than 40 genera have been assigned to the family Flavobacteriaceae, about half of which have been described since 2004. The family Flavobacteriaceae includes species from various habitats, including freshwater, brackish and marine waters, soil and epibenthic fauna, and members of the family are known to be proficient in degrading various biopolymers such as cellulose, chitin and pectin (Kirchman, 2002). Recently, phylogenetic analyses have revealed that many marine species in the family clustered together into a well-defined 'marine clade' (Bowman \& Nichols, 2005). These marine flavobacteria are known to be important members of the bacterial community in many aquatic environments and have a specialist role in using highmolecular-mass dissolved organic matter (Kirchman, 2002).

Published online ahead of print on 18 November 2005 as DOI 10.1099/ijs.0.64146-0.

The GenBank/EMBL/DDBJ accession number for the 16S rRNA gene sequence of strain CL-TFO9 ${ }^{\top}$ is AY962293.

The complete fatty acid profile of strain CL-TFO9 ${ }^{\top}$ is given in Supplementary Table S1 available in IJSEM Online.
In this study, a bacterium, designated strain CL-TF09 ${ }^{\mathrm{T}}$, affiliated with the 'marine clade' of the family Flavobacteriaceae, was isolated from tidal flat sediment in Ganghwa, Korea. Sediment slurry was spread on a marine agar 2216 (MA; Difco) plate, which was then incubated at $30{ }^{\circ} \mathrm{C}$ for 1 week. Strain CL-TF09 ${ }^{\mathrm{T}}$ was isolated and subsequently purified on MA at $30^{\circ} \mathrm{C}$ four times. The strain was maintained both on MA at $4{ }^{\circ} \mathrm{C}$ and in marine broth $2216(\mathrm{MB}$; Difco) supplemented with $30 \%(\mathrm{v} / \mathrm{v})$ glycerol at $-80{ }^{\circ} \mathrm{C}$.

The 16S rRNA gene was amplified from a single colony by PCR with Taq DNA polymerase (Bioneer) and primers $27 \mathrm{~F}$ and 1492R (Lane, 1991). The PCR product was purified using the AccuPrep PCR purification kit (Bioneer) and cloned using the pCR2.1 TOPO TA cloning kit (Invitrogen). Sequencing of the 16S rRNA gene was performed with an Applied Biosystems automatic sequencer (ABI3730XL) at Macrogen, Seoul, Korea. The almost complete 16S rRNA gene sequence of strain CL-TF09 ${ }^{\mathrm{T}}$ (1444 bp) was obtained. The sequence was compared with those available in the GenBank using BLAST-N searches (Altschul et al., 1990). The $16 \mathrm{~S}$ rRNA gene sequence of strain CL-TF09 ${ }^{\mathrm{T}}$ was manually aligned with those of the type strains of species belonging to genera phylogenetically related to CL-TF09 ${ }^{\mathrm{T}}$ and of the type species of other genera in the family Flavobacteriaceae obtained from GenBank and the Ribosomal Database Project (Cole et al., 2003) databases using known 16S rRNA gene secondary structure information. Phylogenetic 
trees were obtained by use of the neighbour-joining (Saitou \& Nei, 1987), maximum-parsimony (Fitch, 1971) and maximum-likelihood (Felsenstein, 1981) methods. An evolutionary distance matrix for the neighbour-joining method was generated according to the model of Jukes \& Cantor (1969). The robustness of tree topologies was assessed by bootstrap analyses based on 1000 replications for the neighbour-joining and maximum-parsimony methods and 100 replications for the maximum-likelihood method. Alignment analysis was carried out using the jPHYDIT program (version 1.0, available at http://chunlab.snu.ac.kr/jphydit/), and phylogenetic analyses were carried out using MEGA 3 (Kumar et al., 2004) and PAUP* 4.0 (Swofford, 1998). Likelihood parameters were estimated by the hierarchical ratio tests in MODELTEST version 3.04 (Posada \& Crandall, 1998). Sequence similarity indicated that the closest relatives of strain CL-TF09 ${ }^{\mathrm{T}}$ belonged to the genera Tenacibaculum $(90 \cdot 6-91 \cdot 8 \%)$ and Polaribacter $(91 \cdot 0-91 \cdot 5 \%)$. Phylogenetic analyses based on $16 \mathrm{~S}$ rRNA gene sequences revealed that strain CL-TF09 ${ }^{\mathrm{T}}$ formed a very robust clade with Tenacibaculum and Polaribacter species, but could not be linked to any of the known genera in the family Flavobacteriaceae (Fig. 1). Thus, strain CL-TF09 ${ }^{\mathrm{T}}$ was recognized as representing a new genus. The DNA G $+\mathrm{C}$ content was determined by HPLC analysis of deoxyribonucleosides as described by Mesbah et al. (1989) after DNA purification following the method of Marmur (1961). The DNA G +C content was $33.9 \mathrm{~mol} \%$.

Morphological and physiological analyses were also performed. Gram-staining was performed as described by Smibert \& Krieg (1994). Cell morphology was examined by phase-contrast microscopy and transmission electron microscopy (JEOL EX2) with cells grown at $30^{\circ} \mathrm{C}$ in $\mathrm{MB}$. Gliding motility was observed by the hanging drop method (Suzuki et al., 2001). Anaerobic growth was checked on MA using the GasPak anaerobic system (BBL). Catalase and oxidase activities were determined according to the protocols described by Smibert \& Krieg (1994), and gelatinase, amylase, DNase, nitrate reductase activities and degradation of Tween 80 were examined as described by Hansen \& Sørheim (1991). Cells of strain CL-TF09 ${ }^{\mathrm{T}}$ were rods $0 \cdot 3-0 \cdot 8 \mu \mathrm{m}$ in width and $1 \cdot 0-5 \cdot 7 \mu \mathrm{m}$ in length when in the exponential growth phase, but irregular rods or spherical cells were observed in older cultures (Fig. 2). Cells were nonmotile (Table 1). Colonies on MA were circular, smooth, entire, convex, shining and yellow. After 1 week incubation, colonies were about $2 \mathrm{~mm}$ in diameter.

The temperature range for growth was determined on the basis of colony formation on MA plates incubated at $5-45^{\circ} \mathrm{C}$. The $\mathrm{pH}$ range (5-11) for growth was determined by changes in $\mathrm{OD}_{600}$ with time in $\mathrm{MB}$. The final $\mathrm{pH}$ was adjusted using $\mathrm{NaOH}$ and $\mathrm{HCl}$ solutions. Tolerance of CLTF09 ${ }^{\mathrm{T}}$ to sea salts was determined using synthetic ZoBell broth $(5 \mathrm{~g}$ Bacto peptone, $1 \mathrm{~g}$ yeast extract, $0 \cdot 1 \mathrm{~g}$ ferric citrate, per litre distilled water) with various concentrations $(0,1,3,5,7,10,15,20,25 \%, \mathrm{w} / \mathrm{v})$ of sea salts (Sigma). Growth in a medium with $\mathrm{NaCl}$ as the sole salt was tested in synthetic ZoBell agar medium supplemented with $3 \% \mathrm{NaCl}$. Nitrate reduction, production of indole, arginine dihydrolase, urease, gelatinase and $\beta$-galactosidase, acid production from glucose, and hydrolysis of aesculin were tested using the API 20NE kit (bioMérieux) according to the

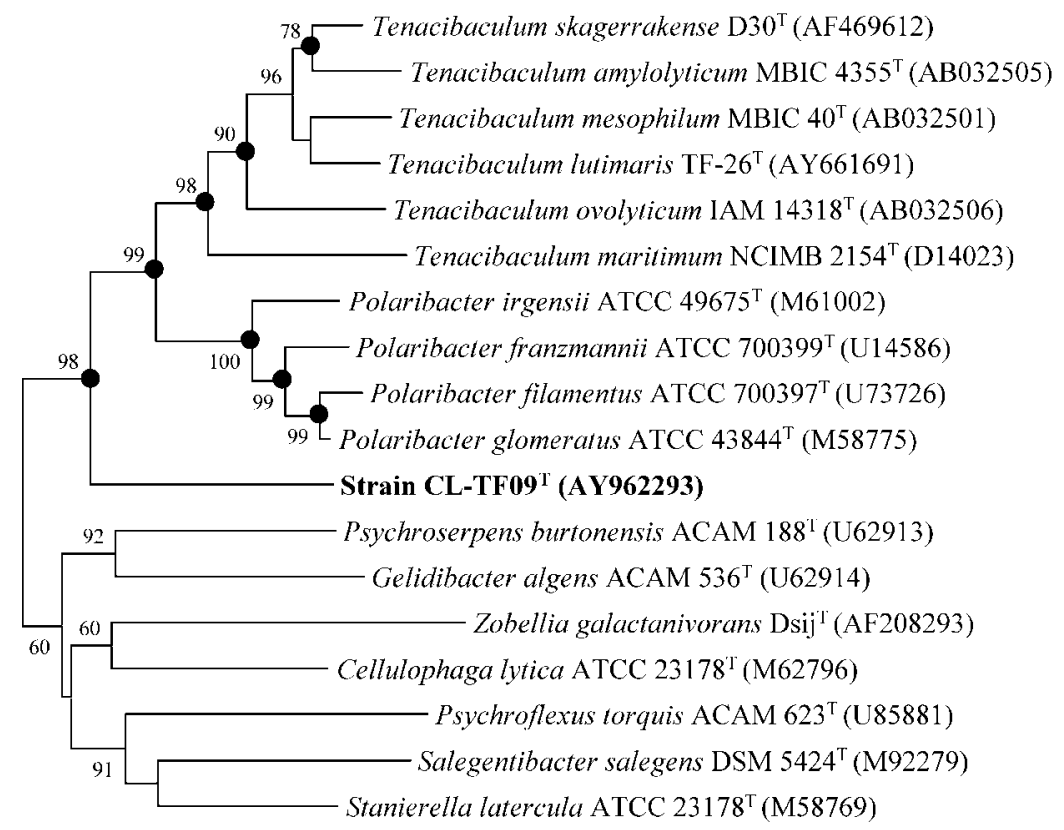

0.02
Fig. 1. Neighbour-joining tree based on $16 \mathrm{~S}$ rRNA gene sequences showing the relationship between strain CL-TF09 ${ }^{\top}$ and other related species belonging to the 'marine clade' of the family Flavobacteriaceae. Only bootstrap values above $60 \%$ are shown (1000 resamplings) at the branching points. Solid circles indicate that the corresponding nodes are also recovered in maximumlikelihood and maximum-parsimony trees. Flexibacter flexilis (M62794) was used as an outgroup (not shown). Bar, 0.02 nucleotide substitutions per site. 

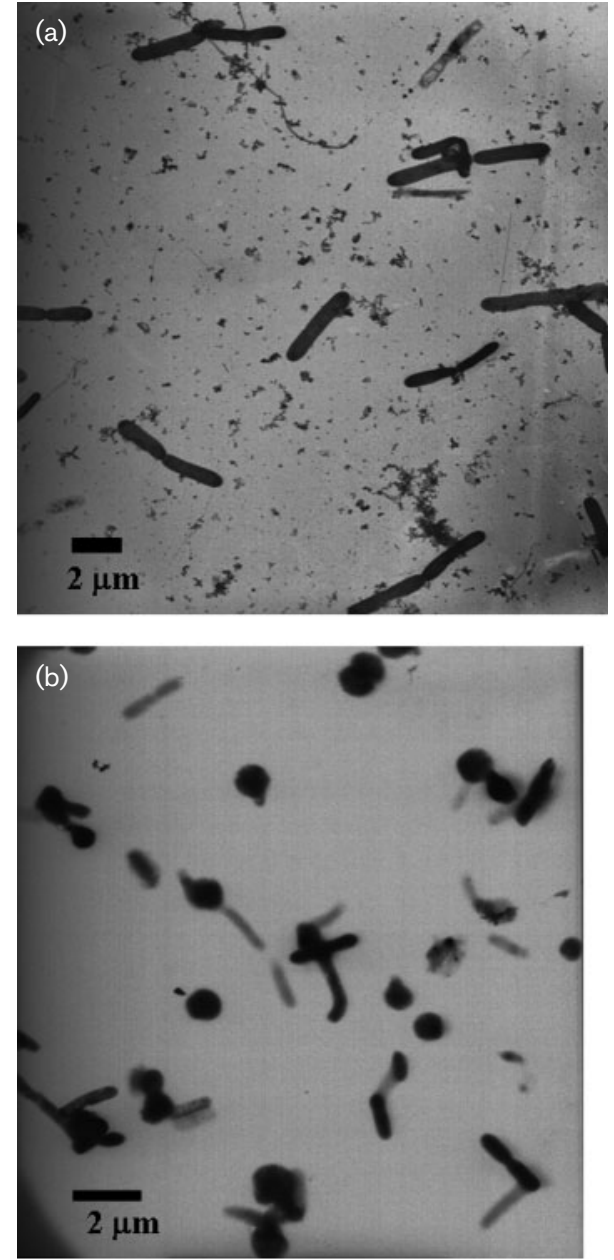

Fig. 2. Transmission electron micrographs of negatively stained cells of strain CL-TFO9 ${ }^{\top}$. Cells were grown at $30^{\circ} \mathrm{C}$ in marine broth for 1 day (a) and on marine agar for 4 days (b).

manufacturer's instructions, except that cell suspension was prepared using artificial sea water [(ASW) $24 \mathrm{~g} \mathrm{NaCl}, 5 \cdot 1 \mathrm{~g}$ $\mathrm{MgCl}_{2}, 4 \mathrm{~g} \mathrm{Na}_{2} \mathrm{SO}_{4}, 1 \cdot 1 \mathrm{~g} \mathrm{CaCl}_{2}, 0 \cdot 7 \mathrm{~g} \mathrm{KCl}, 0 \cdot 2 \mathrm{~g} \mathrm{NaHCO}_{3}$, $0 \cdot 1 \mathrm{~g} \mathrm{KBr}, 0.027 \mathrm{~g} \mathrm{H}_{3} \mathrm{BO}_{3}, 0 \cdot 024 \mathrm{~g} \mathrm{SrCl}_{2}, 0.003 \mathrm{~g} \mathrm{NaF}$, per litre distilled water; Lyman \& Fleming, 1940] as a suspension medium. Carbon utilization was tested on basal agar medium supplemented with yeast extract $(23.6 \mathrm{~g} \mathrm{NaCl}$, $0.64 \mathrm{~g} \mathrm{KCl}, 4.53 \mathrm{~g} \mathrm{MgCl}_{2} .6 \mathrm{H}_{2} \mathrm{O}, 5.94 \mathrm{~g} \mathrm{MgSO}_{4} .7 \mathrm{H}_{2} \mathrm{O}$, $1 \cdot 3 \mathrm{~g} \mathrm{CaCl}_{2} \cdot 2 \mathrm{H}_{2} \mathrm{O}, 0 \cdot 2 \mathrm{~g} \mathrm{NaNO}_{3}, 0 \cdot 2 \mathrm{~g} \mathrm{NH}_{4} \mathrm{Cl}, 15 \mathrm{~g}$ Bacto agar, $0 \cdot 05$ g yeast extract, per litre distilled water; Bruns et al., 2001 ) containing $0 \cdot 2 \%$ of the carbon source. Incubation was prolonged for 1 month and growth was scored as positive when visible colonies were observed. Growth of CL-TF09 ${ }^{\mathrm{T}}$ was observed at temperatures of $5-30{ }^{\circ} \mathrm{C}$, with optimum growth at $25-30^{\circ} \mathrm{C}$. Growth occurred from $\mathrm{pH} 7$ to 8 . The strain could grow at sea salt concentrations from 1 to $5 \%$ but could not grow on agar plates with $3 \% \mathrm{NaCl}$ as the sole salt. Strain CL-TF09 ${ }^{\mathrm{T}}$ could degrade starch, gelatin and aesculin (Table 1). However, it was not able to reduce nitrate to nitrite. CL-TF09 ${ }^{\mathrm{T}}$ was negative for oxidase and weakly positive for $\beta$-galactosidase.

Isoprenoid quinones were isolated according to the method of Minnikin et al. (1984) and analysed by HPLC as described by Collins (1985). The major isoprenoid quinone in CL-TF09 ${ }^{\mathrm{T}}$ was menaquinone-6 (MK-6). Pigments were extracted using $90 \%$ acetone from cells cultured in the dark, and then examined by spectroscopy. Flexirubin-type pigments were detected by using a colour shift test using a $20 \%(\mathrm{w} / \mathrm{v}) \mathrm{KOH}$ solution (Reichenbach, 1992). The spectrum of CL-TF09 ${ }^{\mathrm{T}}$ showed two peaks at 450 and $475 \mathrm{~nm}$ that are typical for carotenoids. The strain did not contain flexirubin-type pigments. Fatty acid methyl esters in whole cells were analysed by GC according to the instructions of the Microbial Identification System (MIDI) at the Korean Culture Center of Microorganisms in Korea. The fatty acid profile for strain CL-TF09 ${ }^{\mathrm{T}}$ was dominated by iso- $\mathrm{C}_{15: 0} 3-\mathrm{OH}(17 \cdot 4 \%)$, iso$\mathrm{C}_{15: 0}(16 \cdot 7 \%)$, anteiso- $\mathrm{C}_{15: 0}(15 \cdot 1 \%)$ and iso- $\mathrm{C}_{16: 0} 3-\mathrm{OH}$ $(13.4 \%)$ (Table 1 ; the complete fatty acid profile of CL-TF09 $^{\mathrm{T}}$ is given in Supplementary Table S1 available in IJSEM Online).

In terms of its phenotypic features, strain CL-TF09 ${ }^{\mathrm{T}}$ could be differentiated from members of the closely related genera Tenacibaculum and Polaribacter based on colony morphology, $\mathrm{pH}$ and temperature range for growth, and biochemical characteristics (Table 1). In particular, hydrolysis of aesculin, a negative response for oxidase, no growth at $\mathrm{pH} 6$, and utilization of pyruvic acid and succinate distinguish strain CL-TF09 ${ }^{\mathrm{T}}$ from members of the genus Tenacibuculum; and growth at $25^{\circ} \mathrm{C}$ and utilization of citrate, L-leucine, tartrate, pyruvic acid and succinate distinguish it from members of the genus Polaribacter (Table 1). In addition, the fatty acid profile of strain CL-TF09 ${ }^{\mathrm{T}}$ clearly distinguishes it from members of the genera Tenacibaculum and Polaribacter (Table 1). In this regard, the major distinctive difference is a large fraction of anteiso- $\mathrm{C}_{15: 0}$ in strain CL-TF09 ${ }^{\mathrm{T}}$. In addition, they were clearly differentiated by the proportions of several fatty acids, including iso- $\mathrm{C}_{16: 0} 3-\mathrm{OH}$, iso- $\mathrm{C}_{15: 1}$ - $\mathrm{G}$ and summed feature $3\left(\mathrm{C}_{16: 1} \omega 7 \mathrm{c} /\right.$ iso- $\left.\mathrm{C}_{15: 0} 2-\mathrm{OH}\right)$.

In conclusion, phylogenetic analyses based on $16 \mathrm{~S}$ rRNA gene sequences, fatty acid profiles and phenotypic features suggest that strain $\mathrm{CL}-\mathrm{TF} 09^{\mathrm{T}}$ should be classified as the type strain of a novel genus and species, for which the name Lutibacter litoralis gen. nov., sp. nov. is proposed.

\section{Description of Lutibacter gen. nov.}

Lutibacter (Lu.ti.bac'ter. L. n. lutum mud; N.L. masc. n. bacter rod; N.L. masc. n. Lutibacter rod from mud).

Cells are Gram-negative and rod-shaped. Growth is heterotrophic and aerobic. Catalase-positive and oxidase-negative. The predominant menaquinone is MK-6. Dominant fatty acids are iso- $\mathrm{C}_{15: 0} 3-\mathrm{OH}$, iso- $\mathrm{C}_{15: 0}$, anteiso- $\mathrm{C}_{15: 0}$ and iso- $\mathrm{C}_{16: 0} 3-\mathrm{OH}$. Cells contain carotenoids but no flexirubin-type pigments. The genus is a member of the 
Table 1. Selected differential characteristics of strain CL-TFO ${ }^{\top}$ and other phylogenetically related genera

Taxa: 1, strain CL-TF09 ${ }^{\mathrm{T}}$; 2, Tenacibaculum; 3, Polaribacter. Data from Gosink et al. (1998), Suzuki et al. (2001), Frette et al. (2004), Yoon et al. (2005), Choi et al. (2006) and this study. +, Positive; -, negative; $\mathrm{V}$, variable between species; NA, not available.

\begin{tabular}{|c|c|c|c|}
\hline & 1 & 2 & 3 \\
\hline Habitat & Tidal flat & $\begin{array}{l}\text { Sea water, tidal flat, } \\
\text { saprophytic or parasitic }\end{array}$ & Sea water or saprophytic \\
\hline Pigment production & + & $\mathrm{V}^{\star}$ & + \\
\hline Gliding motility & - & $\mathrm{V}^{*}$ & - \\
\hline \multicolumn{4}{|l|}{ Colony: } \\
\hline Colour & Yellow & Yellow, pale yellow & Orange, salmon pink \\
\hline Shape & Entire & Uneven edge & Entire \\
\hline Sea salt requirement & + & $\mathrm{V}$ & $\mathrm{V}$ \\
\hline \multicolumn{4}{|l|}{ Growth at: } \\
\hline $\mathrm{pH} 6$ & - & + & NA \\
\hline $25^{\circ} \mathrm{C}$ & + & + & - \\
\hline $37^{\circ} \mathrm{C}$ & - & $\mathrm{V}$ & - \\
\hline \multicolumn{4}{|l|}{ Hydrolysis of: } \\
\hline Starch & + & $\mathrm{V}$ & + \\
\hline Gelatin & + & $+\dagger$ & $\mathrm{v}$ \\
\hline Aesculin & + & - & $\mathrm{V}$ \\
\hline Nitrate reductase activity & - & $\mathrm{V}$ & $\mathrm{V} 末$ \\
\hline Oxidase activity & - & + & $\mathrm{V}$ \\
\hline \multicolumn{4}{|l|}{ Major fatty acids (\%)\$: } \\
\hline iso- $\mathrm{C}_{15: 1}-\mathrm{G}$ & 4 & NDll & $6-12$ \\
\hline anteiso- $\mathrm{C}_{15: 0}$ & 15 & $1-2$ & $4-6$ \\
\hline iso- $\mathrm{C}_{16: 0} 3-\mathrm{OH}$ & 13 & $5-13$ & $\mathrm{ND}$ \\
\hline iso- $\mathrm{C}_{17: 0} 3-\mathrm{OH}$ & 4 & $8-15$ & ND \\
\hline Summed feature $3 \#$ & 1 & $18-24$ & $2-9$ \\
\hline \multicolumn{4}{|l|}{ Carbon utilization: } \\
\hline Citrate & + & $\mathrm{V}$ & - \\
\hline Glycerol & - & $-* *$ & $\mathrm{~V}$ \\
\hline L-Leucine & + & V & - \\
\hline Tartrate & + & NA & - \\
\hline Pyruvic acid & + & $-* *$ & - \\
\hline Succinate & + & $-* *$ & - \\
\hline Sucrose & - & $\mathrm{V}$ & $\mathrm{V}$ \\
\hline L-Proline & - & $\mathrm{V}$ & - \\
\hline L-Glutamate & - & V & V \\
\hline
\end{tabular}

*All species except Tenacibaculum skagerrakense are positive for this characteristic.

$\dagger$ †ata not available for Tenacibaculum skagerrakense.

¥All species except Polaribacter glomeratus are negative for this characteristic.

§Data for Tenacibaculum are from Tenacibaculum lutimaris, Tenacibaculum skagerrakense, Tenacibaculum mesophilum and Tenacibaculum maritimum; data for Polaribacter are from Polaribacter filamentus, Polaribacter irgensii and Polaribacter franzmannii. CL-TF0 $9^{\mathrm{T}}$ and Tenacibaculum species were grown on marine agar 2216 at $30^{\circ} \mathrm{C}$ for 1-2 days, whereas Polaribacter species were grown on sea water-cytophaga media at $5{ }^{\circ} \mathrm{C}$ for $3-4$ weeks.

IINot detected or $<1 \%$.

SNot detected or $<5 \%$.

$\# \mathrm{C}_{16: 1} \omega 7$ c/iso- $\mathrm{C}_{15: 0}$ 2-OH

${ }^{*}$ Data not available for $T$. lutimaris. 
family Flavobacteriaceae. The type species is Lutibacter litoralis.

\section{Description of Lutibacter litoralis sp. nov.}

Lutibacter litoralis (li.to.ra'lis. L. masc. adj. litoralis of the shore).

Exhibits the following properties in addition to those given in the genus description. Cells are approximately $0 \cdot 3-0 \cdot 8 \mu \mathrm{m}$ wide and $1 \cdot 0-5 \cdot 7 \mu \mathrm{m}$ long. Spherical cells appear in ageing culture. Cells are non-motile. On MA medium, colonies are circular, entire, convex, shining, opaque and yellow. Absorption spectral peaks of the pigments are observed at 450 and $475 \mathrm{~nm}$. Growth occurs at 5-30 ${ }^{\circ} \mathrm{C}$ (optimum 25 $30^{\circ} \mathrm{C}$ ) and at $\mathrm{pH}$ values of between 7 and 8 . Growth occurs at sea salt concentrations of $1-5 \%(\mathrm{w} / \mathrm{v})$. Catalase, amylase, gelatinase and DNase activities are positive. Cytochrome oxidase, nitrate reductase and Tween 80 hydrolysis activities are negative. According to API 20NE tests, aesculin hydrolysis and gelatinase activities are positive, whereas nitrate reductase, indole production, acid production from glucose, arginine dihydrolase and urease are negative. Growth occurs on acetone, citrate, D-fructose, D-raffinose, D-salicin, D-sorbitol, glycine, glycogen, myo-inositol, L-arginine, L-lysine, L-ornithine, pyruvic acid, succinate, tartrate, urea, Casamino acids, L-leucine, peptone, tryptone and yeast extract. No growth occurs on acetate, acetamide, $\alpha$-ketobutyric acid, benzoate, DL-cysteine, D-cellobiose, D-galactose, D-glucose, D-mannitol, D-mannose, D-ribose, D-trehalose, D-xylose, ethanol, formic acid, glycerol, inulin, 2-propanol, lactose, L-arabinose, L-ascorbate, L-asparagine, L-rhamnose, maleic acid, $\mathrm{N}$-acetylglucosamine, polyethylene glycol, salicylate, sucrose, thiamine, DL-aspartate, L-proline or L-glutamate. The DNA $\mathrm{G}+\mathrm{C}$ content is $33 \cdot 9 \mathrm{~mol} \%$.

The type strain, CL-TF09 $9^{\mathrm{T}} \quad\left(=\mathrm{KCCM} \quad 42118^{\mathrm{T}}=\mathrm{JCM}\right.$ $\left.13034^{\mathrm{T}}\right)$, was isolated from a tidal flat sediment in Ganghwa, Korea.

\section{Acknowledgements}

This work was supported in part by the Special Grants Research Program in Fisheries (MOMAF) to B.C.C. (20010021) and by the BK21 project of the Korean Government.

\section{References}

Altschul, S. F., Gish, W., Miller, W., Myers, E. W. \& Lipman, D. J. (1990). Basic local alignment search tool. J Mol Biol 215, 403-410.

Bernardet, J.-F., Segers, P., Vancanneyt, M., Berthe, F., Kersters, K. \& Vandamme, P. (1996). Cutting a Gordian knot: emended classification and description of the genus Flavobacterium, emended description of the family Flavobacteriaceae, and proposal of Flavobacterium hydatis nom. nov. (basonym, Cytophaga aquatilis Strohl and Tait 1978). Int J Syst Bacteriol 46, 128-148.

Bernardet, J.-F., Nakagawa, Y. \& Holmes, B. (2002). Proposed minimal standards for describing new taxa of the family
Flavobacteriaceae and emended description of the family. Int J Syst Evol Microbiol 52, 1049-1070.

Bowman, J. P. \& Nichols, D. S. (2005). Novel members of the family Flavobacteriaceae from Antarctic maritime habitats including Subsaximicrobium wynnwilliamsii gen. nov., sp. nov., Subsaximicrobium saxinquilinus sp. nov., Subsaxibacter broadyi gen. nov., sp. nov., Lacinutrix copepodicola gen. nov., sp. nov., and novel species of the genera Bizionia, Gelidibacter and Gillisia. Int J Syst Evol Microbiol 55, 1471-1486.

Bruns, A., Rohde, M. \& Berthe-Corti, L. (2001). Muricauda ruestringensis gen. nov., sp. nov., a facultatively anaerobic, appendaged bacterium from German North sea intertidal sediment. Int J Syst Evol Microbiol 51, 1997-2006.

Choi, D. H., Kim, Y. G., Hwang, C. Y., Yi, H., Chun, J. \& Cho, B. C. (2006). Tenacibaculum litoreum sp. nov., isolated from tidal flat sediment. Int J Syst Evol Microbiol 56, 635-640.

Cole, J. R., Chai, B., Marsh, T. L. \& 8 other authors (2003). The Ribosomal Database Project (RDP-II): previewing a new autoaligner that allows regular updates and the new prokaryotic taxonomy. Nucleic Acids Res 31, 442-443.

Collins, M. D. (1985). Analysis of isoprenoid quinones. Methods Microbiol 18, 329-366.

Felsenstein, J. (1981). Evolutionary trees from DNA sequences: a maximum likelihood approach. J Mol Evol 17, 368-376.

Fitch, W. M. (1971). Toward defining the course of evolution: minimum change for a specific tree topology. Syst Zool 20, 406-416.

Frette, L., Jørgensen, N. O. G., Irming, H. \& Kroer, N. (2004). Tenacibaculum skagerrakense sp. nov., a marine bacterium isolated from the pelagic zone in Skagerrak, Denmark. Int J Syst Evol Microbiol 54, 519-524.

Garrity, G. M. \& Holt, J. G. (2001). The road map to the Manual. In Bergey's Manual of Systematic Bacteriology, 2nd edn, vol. 1, pp. 119-168. Edited by D. R. Boone, R. W. Castenholtz \& G. M. Garrity. New York: Springer.

Gosink, J. J., Woese, C. R. \& Staley, J. T. (1998). Polaribacter gen. nov., with three new species, $P$. irgensii sp. nov., $P$. franzmannii sp. nov. and $P$. filamentus sp. nov., gas vacuolate polar marine bacteria of the Cytophaga-Flavobacterium-Bacteroides group and reclassification of 'Flectobacillus glomeratus' as Polaribacter glomeratus comb. nov. Int J Syst Bacteriol 48, 223-235.

Hansen, G. H. \& Sorheim, R. (1991). Improved method for phenotypical characterization of marine bacteria. J Microbiol Methods 13, 231-241.

Jooste, P. J. (1985). The taxonomy and significance of FlavobacteriumCytophaga strains from dairy sources. $\mathrm{PhD}$ thesis, University of the Orange Free State.

Jukes, T. H. \& Cantor, C. R. (1969). Evolution of protein molecules. In Mammalian Protein Metabolism, pp. 21-132. Edited by H. N. Munro. New York: Academic Press.

Kirchman, D. L. (2002). The ecology of Cytophaga-Flavobacteria in aquatic environments. FEMS Microbiol Ecol 39, 91-100.

Kumar, S., Tamura, K. \& Nei, M. (2004). MEGA 3: integrated software for molecular evolutionary genetics analysis and sequence alignment. Brief Bioinform 5, 150-163.

Lane, D. J. (1991). 16S/23S rRNA sequencing. In Nucleic Acid Techniques in Bacterial Systematics, pp. 115-175. Edited by E. Stackebrandt \& M. Goodfellow. Chichester: Wiley.

Lyman, J. \& Fleming, R. H. (1940). Composition of sea water. J Mar Res 3, 134-146.

Marmur, J. (1961). A procedure for the isolation of deoxyribonucleic acid from microorganisms. J Mol Biol 3, 208-218. 
Mesbah, M., Premachandran, U. \& Whitman, W. B. (1989). Precise measurement of the $\mathrm{G}+\mathrm{C}$ content of deoxyribonucleic acid by high performance liquid chromatography. Int J Syst Bacteriol 39, 159-167.

Minnikin, D. E., O'Donnell, A. G., Goodfellow, M., Alderson, G., Athalye, M., Schaal, K. \& Parlett, J. H. (1984). An integrated procedure for the extraction of bacterial isoprenoid quinones and polar lipids. J Microbiol Methods 2, 233-241.

Posada, D. \& Crandall, K. A. (1998). MODELTEST: testing the model of DNA substitution. Bioinformatics 14, 817-818.

Reichenbach, H. (1992). The order Cytophagales. In The Prokaryotes. A Handbook on the Biology of Bacteria: Ecophysiology, Isolation, Identification, Applications, 2nd edn, pp. 3631-3675. Edited by A. Balows, H. G. Trüper, M. Dworkin, W. Harder \& K. H. Schleifer. New York: Springer.

Saitou, N. \& Nei, M. (1987). The neighbor-joining method: a new method for reconstructing phylogenetic trees. Mol Biol Evol 4, 406-425.
Smibert, R. M. \& Krieg, N. R. (1994). Phenotypic characterization. In Methods for General and Molecular Bacteriology, pp. 607-654. Edited by P. Gerhardt, R. G. E. Murray, W. A. Wood \& N. R. Krieg. Washington, DC: American Society for Microbiology.

Suzuki, M., Nakagawa, Y., Harayama, S. \& Yamamoto, S. (2001). Phylogenetic analysis and taxonomic study of marine Cytophaga-like bacteria: proposal for Tenacibaculum gen. nov. with Tenacibaculum maritimum comb. nov. and Tenacibaculum ovolyticum comb. nov., and description of Tenacibaculum mesophilum sp. nov. and Tenacibaculum amylolyticum sp. nov. Int J Syst Evol Microbiol 51, 1639-1652.

Swofford, D. L. (1998). PAUP*. Phylogenetic Analysis Using Parsimony, version 4. Sunderland, MA: Sinauer Associates.

Yoon, J.-H., Kang, S.-J. \& Oh, T.-K. (2005). Tenacibaculum lutimaris sp. nov., isolated from a tidal flat in the Yellow Sea, Korea. Int J Syst Evol Microbiol 55, 793-798. 